\title{
PERTUMBUHAN TANAMAN KELAPA SAWIT DI LAHAN PASANG SURUT
}

\section{Oil Palm Growth on tidal land}

\author{
Winarna, H. Santoso, M. A. Yusuf, Sumaryanto, E. S. Sutarta \\ Pusat Penelitian Kelapa Sawit (PPKS) Medan \\ Jl. Brigjen Katamso No. 51 Medan 20158 \\ Corresponding author : winarna@iopri.org.
}

\begin{abstract}
Limitations of potential land for palm oil industry in Indonesia led to the development of mature oil palm plantations leads to marginal lands with various limiting factors. One of the marginal land that could potentially as alternative for palm oil development is the tidal wet lands. The potential of tidal land for oil palm cultivation is mainly related to the flat topography and water availability throughout the year that to minimize the possibility of water deficit. However, there are some critical issues that become limiting for the development of oil palm plantations, which severely hampered drainage, high salinity, the potential content of pyrite, peat depth and maturity, as well as greater investment for infrastructure development. Growth and productivity of oil palm trees in addition to tidal land affected by the improvement in the fertility rate is also influenced by water management. The observation of vegetative ( leaf area ) of oil palm plantations age of 2 years in a swamp area pitu ( pyrite $80-100 \mathrm{~cm}$ depth ) showed that the water management in water level of $20-40 \mathrm{~cm}$ had greater leaf area ( $2.93 \mathrm{~m} 2$ ) compared with water management $0-20 \mathrm{~cm}(2.40 \mathrm{~m} 2)$ and $40-60 \mathrm{~cm}(2.21 \mathrm{~m} 2)$ below the ground surface . According Winarna ( 2007 ), the productivity of oil palm plantations aged 10 years on acid sulfate soil in North Sumatra with water management and good pyrite can reach the range of 20-24 tonnes FFB / ha / year. The results of the observations made by Harahap and Siregar (2004) at the age of oil palm plantation in Betong Krawo 5-6 years ( kedalaan pyrite $50-100 \mathrm{~cm}$ ) with water management and pyrite are not maximized, which indicates that the low productivity range $10.86-12.70$ tonnes FFB / ha / year .
\end{abstract}

Keywords : Palm oil, growth, tidal land

\begin{abstract}
ABSTRAK
Keterbatasan lahan yang potensial untuk industri kelapa sawit di Indonesia menyebabkan pembangunan perkebunan kelapa sawit dewasa ini mengarah ke lahan marjinal dengan berbagai faktor pembatas. Salah satu lahan marjinal yang berpotensi menjadi alternatf untuk pengembangan kelapa sawit adalah lahan rawa pasang surut. Potensi lahan pasang surut untuk budidaya kelapa sawit terutama terkait dengan topografi yang datar dan ketersediaan air sepanjang tahun sehingga memperkecil kemungkinan terjadi defisit air. Meskipun demikian, terdapat beberapa masalah kritis yang menjadi pembatas bagi pengembangan perkebunan kelapa sawit, yaitu drainase yang sangat terhambat, salinitas
\end{abstract}


yang tinggi, potensi kandungan pirit, kedalaman dan kematangan gambut, serta investasi yang lebih besar untuk pembangunan infrastruktur. Pertumbuhan dan produktivitas tanaman kelapa sawit di lahan pasang surut selain dipengaruhi oleh perbaikan tingkat kesuburan juga di pengaruhi oleh pengelolaan air. Hasil pengamatan vegetatif (leaf area) tanaman kelapa sawit umur 2 tahun di daerah rawa pitu (kedalaman pirit $80-100 \mathrm{~cm}$ ) menunjukkan bahwa pengelolan air dengan tinggi muka air 20-40 cm memiliki leaf area yang lebih besar $\left(2,93 \mathrm{~m}^{2}\right)$ dibandingkan dengan pengelolaan air 0-20 $\mathrm{cm}\left(2,40 \mathrm{~m}^{2}\right)$ dan $40-60 \mathrm{~cm}\left(2,21 \mathrm{~m}^{2}\right)$ di bawah permukaan tanah. Menurut Winarna et al. (2007), produktivitas tanaman kelapa sawit umur 10 tahun pada tanah sulfat masam di Sumatera Utara dengan pengelolaan air dan pirit yang baik dapat mencapai kisaran $20-24$ ton TBS/ha/tahun. Hasil pengamatan yang dilakukan oleh Harahap dan Siregar (2004) pada tanaman kelapa sawit umur 5-6 tahun di Betung Krawo (kedalaan pirit 50-100 cm) dengan pengelolaan air dan pirit yang belum maksimal, menunjukan bahwa produktivitasnya rendah yaitu berkisar $10,86-12,70$ ton TBS/ha/tahun.

Kata kunci: Kelapa sawit, pertumbuhan, lahan pasang surut.

\section{PENDAHULUAN}

Peluang usaha agribisnis perkebunan kelapa sawit di Indonesia cukup terbuka berkaitan dengan meningkatnya permintaan minyak kelapa sawit dunia. Dewasa ini terdapat lebih kurang 10 juta ha areal perkebunan kelapa sawit (Dirjenbun, 2013). Meskipun demikian, usaha agribisnis perkebunan kelapa sawit di Indonesia saat ini dihadapkan pada keterbatasan sumber daya lahan yang memiliki karakteristik optimum untuk pertumbuhan dan produksi tanaman kelapa sawit, sehingga pengembangan perkebunan kelapa sawit di Indonesia akhirnya mengarah ke lahan-lahan marjinal dengan berbagai faktor pembatas seperti lahan dengan topografi curam dan lahan rawa (rawa pasang surut termasuk lahan gambut).

Lahan pasang surut memiliki potensi untuk pengembangan kelapa sawit baik didasarkan pada karakteristik lahan maupun luasannya, namun demikian masalah utama yang dihadapi adalah kondisi drainase yang terhambat tergenang. Agar perakaran tanaman kelapa sawit dapat berkembang setidaknya diperlukan lapisan yang tidak tergenang air sedalam $50-75 \mathrm{~cm}$ dan idealnya adalah $\geq 100 \mathrm{~cm}$ (Winarna et al, 2007). Penurunan permukaan air tanah ini dapat menjadi masalah pada tanah sulfat masam, karena dapat menyebabkan oksidasi mineral pirit khususnya pada lapisan pirit yang berada dekat permukaan tanah. Mengingat penurunan permukaan air merupakan suatu keharusan agar perakaran kelapa sawit di lahan pasang surut dapat berke mbang, parameter kedalaman mineral pirit menjadi faktor penting dalam menilai kesesuaian lahan rawa pasang surut untuk tanaman kelapa sawit.

Pengembangan kelapa sawit di lahan pasang surut akan dihadapkan pada berbagai tantangan terkait dengan karakteristik tanah pada lahan pasang surut, yaitu tantangan dalam pengelolaan lahan, kultur teknis maupun investasi untuk pembangunan infrastruktur. Untuk itu, pengembangan lahan rawa pasang surut memerlukan perencanaan, pengelolaan, dan pemanfaatan yang tepat serta penerapan teknologi yang sesuai, terutama pengelolaan tanah dan air. Dengan upaya seperti itu diharapkan lahan rawa pasang surut dapat menjadi lahan pertanian/perkebunan yang 
produktif, berkelanjutan, dan berwawasan lingkungan (Suriadikarta, 2005).

\section{1. potensi lahan rawa pasang surut di Indonesia untuk budidaya kelapa sawit}

Luas lahan pasang surut di Indonesia sangat luas. Menurut data dari Dinas Kimpraswil, terdapat sekitar 39,4 juta ha yang tersebar di Sumatera, Kalimantan dan Papua (Tabel 1). Luas lahan rawa pasang surut di pulau Sumatera, berkisar 13,2 juta ha (Kimpraswil, 2006), 6 juta ha diantaranya berpotensi untuk pengembangan sektor pertanian/perkebunan (Suba gyono, et.al 1994 dalam Subagyono \& Susanti, 1998). Luas lahan rawa pasang surut yang berpotensi untuk pengembangan kelapa sawit belum diperoleh data pasti, mengingat diperlukan studi khusus untuk dapat memperoleh informasi ini. Meskipun demikian, secara umum lahan rawa pasang surut memiliki potensi untuk budidaya kelapa sawit terutama terkait dengan ketersediaan air sepanjang tahun sehingga memperkecil kemungkinan cekaman kekeringan akibat defisit air. Selain itu topografi areal rawa pasang surut yang datar akan mempermudah pengelolaan perkebunan kelapa sawit.

Tabel 1. Sumberdaya lahan rawa di 3 Pulau Besar (000 ha)

\begin{tabular}{lrcrc}
\hline \multicolumn{1}{c}{$\begin{array}{c}\text { Tipe } \\
\text { Lahan Rawa }\end{array}$} & Sumatera & Kalimantan & Papua & Total \\
\hline $\begin{array}{l}\text { Pasang Surut } \\
\text { (Tidal lowland) }\end{array}$ & 9.771 & 7.054 & 7.798 & 24,707 \\
$\begin{array}{l}\text { Rawa non Pasang surut } \\
\text { (Inland Lowland) }\end{array}$ & 3.440 & 5.710 & 5,181 & 14,716 \\
Total & 13,211 & 12,764 & 12,979 & 39,423 \\
\hline
\end{tabular}

Sumber : Kimpraswil-online, 2006

\section{2. karakteristik lahan rawa pasang surut dan kendala pengelolaan lahan rawa pasang surut}

Widjaja-Adhi (1995 dalam Widjaya-Adhi \& Alihamsyah, 1998) membagi lahan pasang surut berdasarkan macam dan tingkat kendala yang diperkirakan dapat timbul dari faktor fisika-kimia menjadi empat tipologi utama yaitu : 1). lahan potensial; 2). lahan sulfat masam; 3). lahan gambut; dan 4) lahan salin. Lahan potensial merupakan lahan pasang surut termasuk dalam tanah sulfat masam potensial dengan kandungan pirit $2 \%$ pada kedalaman $>50 \mathrm{~cm}$. Lahan sulfat masam merupakan lahan pasang surut dengan kandungan pirit $>2 \%$ pada kedalaman $<50 \mathrm{~cm}$. Lahan gambut merupakan lahan yang terbentuk dari bahan organik dengan kandungan 12-18\% karbon organik (bahan jenuh air) atau 20\% (tidak pernah jenuh air). Lahan salin merupakan lahan pasang surut yang mendapat pengaruh intrusi air laut lebih dari 3 bulan dalam setahun dengan kandungan $\mathrm{Na}$ dalam larutan tanah $>8 \%$.Penciri umum dari lahan pasang surut adalah muka air tanah yang dangkal serta drainase yang buruk dari kategori sangat terhambat hingga tergenang. Fisiografi utama pada lahan pasang surut umumnya termasuk dalam fisiografi marin dan gambut. Ketersediaan air sepanjang tahun sehingga memperkecil kemungkinan terjadi defisit air, namun disisi lain dapat menjadi faktor pembatas akibat drainase yang sangat terhambat sehingga mengakibatkan genangan periodik maupun permanen. Kondisi drainase terhambat akan mengakibatkan dampak buruk bagi tanaman, yaitu terhambatnya perkembangan akar akibat respirasi yang tertekan dan perubahan sifat kimia tanah 
sehingga mengakibatkan menurunnya ketersediaan hara untuk tanaman. Khusus pada tanaman kelapa sawit, kondisi ini akan mengakibatkan gejala defisiensi nitrogen dan hara lainnya pada tanaman yang ditandai dengan keragaan tanaman yang menguning pucat dan pertumbuhannya kerdil. Upaya teknis yang dilakukan untuk mengembangkan tanaman kelapa sawit di lahan rawa pasang surut membutuhkan perhatian yang serius dengan investasi persiapan lahan yang cukup tinggi.

Karakteristik lain yang sangat spesifik pada lahan pasang surut adalah potensi kandungan pirit. Dalam keadaan terbuka, pirit teroksidasi menjadi asam sulfat dan sulfida besi sehingga tanah tidak dapat dimanfaatkan untuk budidaya pertanian maupun perkebunan. Pada tanah yang memiliki pirit teroksidasi, kemasaman tanahnya sangat tinggi serta kandungan $\mathrm{H}^{+}, \mathrm{Al}, \mathrm{Fe}^{3+}$ dan $\mathrm{Mn}$ yang berbahaya bagi tanaman. Kondisi tersebut umumya diikuti oleh rendahnya ketersediaan $\mathrm{P}$ dan hara-hara makro lainnya (Andriese dan Sukardi, 1990 dalam Suriadikarta, 2005). Di Indonesia luas tanah sulfat masam mencapai 2 juta ha yang tersebar di Sumatera, Kalimantan, dan Papua (Hakim et al, 1986). Lapisan pirit (lapisan sulfidik) merupakan faktor penting pembatas pertumbuhan tanaman kelapa sawit di lahan rawa pasang surut. Tanah dengan bahan sulfidik dan horison sulfurik di dalamnya dikenal dengan istilah tanah sulfat masam. Tanah sulfat masam perlu mendapat perhatian berkaitan dengan adanya potensi terjadinya oksidasi mineral pirit yang menyebabkan turunnya $\mathrm{pH}$ tanah sehingga dapat mengganggu pertumbuhan tanaman kelapa sawit. Dalam keadaan teroksidasi, pirit yang berubah menjadi sulfida besi tersebut diikuti dengan peningkatan kemasaman tanah yang tajam yang akan menghambat pertumbuhan tanaman dan menjadi racun bagi tanaman melalui beberapa mekanisme antara lain: 1) kerusakan sel tanaman akibat peningkatan ion $\mathrm{H}^{+}, 2$ ) peningkatan kelarutan $\mathrm{Fe}, \mathrm{Al}$, dan $\mathrm{Mn}$ yang bersifat toksik bagi tanaman, 3) penurunan konsentrasi kation tertukar seperti $K, 4)$ penurunan ketersediaan $P$, 5) terhambatnya pertumbuhan akar dan serapan air, dan abnormalitas faktor biotik (Rorison, dalam Leiwakabessy, 1980).

\section{Pertumbuhan tanaman kelapa sawit di lahan pasang surut}

\section{Tanaman Belum Menghasilkan}

Menurut Toh et. al. (1989) kelapa sawit di lahan rawa pasang surut memiliki masa belum menghasilkan (TBM) lebih panjang yaitu 31-38 bulan, lebih lambat dibanding 26 - 30 bulan pada lahan mineral secara umum. Pengamatan pertumbuhan vegetatif tanaman belum menghasilkan berumur dua tahun (TBM 2) (Varietas Bah Jambi) di lahan pasang surut dilakukan di daerah Rawa Pitu. Parameter pertumbuhan tanaman yang dianalisis meliputi panjang racis, lebar petiola, tebal petiola, jumlah anak daun, dan leaf area. Kedalaman pirit di Blok percobaan sedalam 80-100 $\mathrm{cm}$ dengan perlakuan 3 tinggi muka air tanah, yaitu: 0-20 cm, 20$40 \mathrm{~cm}$, dan 40-60 cm. Hasil pengamatan menunjukkan bahwa secara umum keragaan vegetatif tanaman kelapa sawit di areal pasang surut dengan sistem tata kelola muka air 20-40 cm dibawah permukaan tanah memiliki nilai lebih tinggi dibandingkan keragaan vegetatif di tanah mineral. Leaf area terbesar terdapat pada perlakuan tinggi muka air $20-40 \mathrm{~cm}$. 
Tabel 2. Keragaan vegetatif TBM 2 kelapa sawit pada lahan pasang surut dengan beberapa ketinggian muka air dan pada lahan mineral.

\begin{tabular}{lccccc}
\hline Muka Air & $\begin{array}{c}\text { Panjang } \\
\text { Rachis } \\
(\mathbf{m})\end{array}$ & $\begin{array}{c}\text { Lebar } \\
\text { Petiola } \\
(\mathbf{c m})\end{array}$ & $\begin{array}{c}\text { Tebal } \\
\text { Petiola } \\
(\mathbf{c m})\end{array}$ & $\begin{array}{c}\text { Jumlah } \\
\text { anak daun }\end{array}$ & $\begin{array}{c}\text { LA } \\
(\text { Leaf } \\
\text { Area })\end{array}$ \\
\hline \multicolumn{7}{c}{ Lahan Pasang Surut } \\
\hline $\mathbf{0 - 2 0} \mathbf{~ c m}$ & 2,45 & 3,65 & 2,21 & 199 & 2,40 \\
$\mathbf{2 0 - 4 0 ~ c m ~}$ & 2,43 & 3,87 & 2,44 & 214 & 2,93 \\
$\mathbf{4 0 - 6 0 ~ c m ~}$ & 2,28 & 3,52 & 2,18 & 193 & 2,21 \\
\hline \multicolumn{6}{c}{ Lahan Mineral } \\
\hline Mineral 1 & 2,80 & 4,04 & 2,85 \\
Mineral 2 & 2,90 & 4,39 & 2,75 & 197 & 2,76 \\
\hline
\end{tabular}

Hasil pengamatan perkembangan luas area daun (leaf area) $\left(\mathrm{m}^{2}\right)$ tanaman kelapa sawit belum menghasilkan pada umur 15, 19, 22, 24 bulan dengan ketinggian muka air yang berbeda menunjukkan bahwa pada perlakuan dengan tinggi muka air 20-40 $\mathrm{cm}$ dibawah permukaan tanah memiliki pertumbuhan paling tinggi dibandingkan dengan perlakuan tinggi muka air 0-20 $\mathrm{cm}$ dan 40-60 $\mathrm{cm}$ dibawah permukaan tanah (Gambar 1). Keragaan leaf area tanaman kelapa sawit pada umur 15, 19, 22 , dan 24 bulan pada areal pasang surut dengan tinggi muka air tanah yang berbeda tersaji pada tabel 3

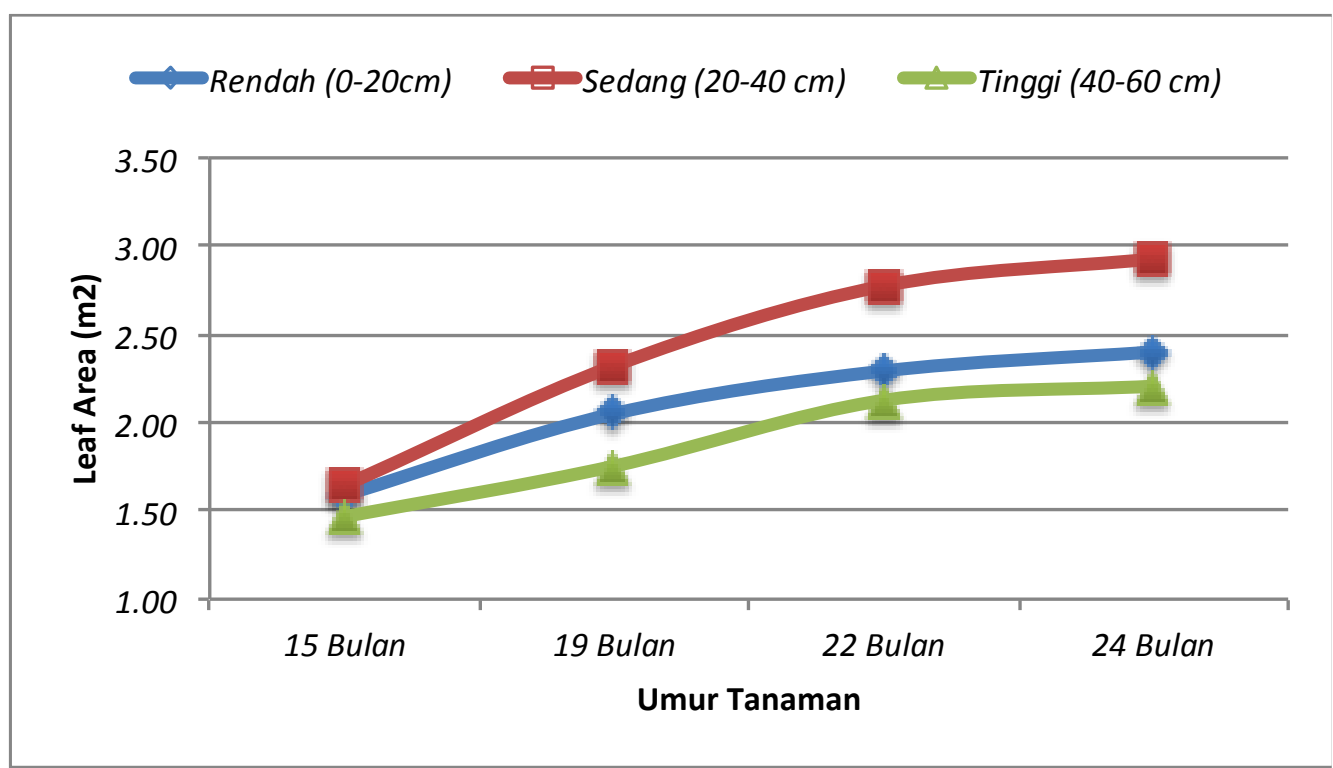

Gambar 1. Grafik perkembangan leaf area tanaman kelapa sawit pada umur $15,19,22$, dan 24 bulan pada areal pasang surut dengan tinggi muka air tanah yang berbeda. 
Tabel 3. Keragaan leaf area tanaman kelapa sawit pada umur 15, 19, 22, dan 24 bulan pada areal pasang surut dengan tinggi muka air tanah yang berbeda.

\begin{tabular}{lrrrr}
\hline \multirow{2}{*}{ Tinggi Muka Air } & \multicolumn{4}{c}{ Leaf Area $\left(\mathrm{m}^{2}\right)$ tanaman Kelapa Sawit pada umur } \\
\cline { 2 - 5 } & 15 Bulan & 19 Bulan & 22 Bulan & 24 Bulan \\
\hline Rendah $(0-20 \mathrm{~cm})$ & 1.59 & 2.05 & 2.29 & 2.40 \\
Sedang $(20-40 \mathrm{~cm})$ & 1.64 & 2.32 & 2.78 & 2.93 \\
Tinggi $(40-60 \mathrm{~cm})$ & 1.46 & 1.75 & 2.13 & 2.21 \\
\hline
\end{tabular}

\section{Tanaman menghasilkan}

Pengamatan vegetatif kelapa sawit tahun tanam 1998 di daerah Betung Krawo, menunjukkan bahwa pertumbuhan vegetatif pada areal berpirit dalam memiliki nilai yang lebih tinggi (lebih jagur) dibanding pertumbuhan tanaman pada areal dengan lapisan pirit dangkal (Tabel 4). Rerata tinggi tanaman kelapa sawit pada jenis tanah Sulfic Endoaquepts (kedalaman pirit $100 \mathrm{~cm}$ ) mencapai $243 \mathrm{~cm}$, sementara rerata tinggi tanaman kelapa sawit pada tanah Typic Sulfaquepts (pirit dangkal) hanya 131 $\mathrm{cm}$. Selain itu rerata jumlah anak daun (daun ke-17) tanaman kelapa sawit pada jenis tanah Sulfic Endoaquepts mencapai 318, sedangkan tanaman kelapa sawit pada jenis tanah Typic Sulfaquepts memiliki jumlah anak daun lebih sedikit yaitu sebanyak 260 . Namun secara statistik kedua parameter pertumbuhan tanaman pada tanah Sulfic Endoaquepts dan Typic Sulfaquepts tersebut tidak beda nyata. Pertumbuhan tanaman pada kedalaman pirit yang berbeda secara lengkap tersaji pada tabel 4 .

Tabel 4. Pertumbuhan tanaman pada kedalaman pirit yang berbeda

\begin{tabular}{lcccc}
\hline Jenis Tanah & Blok & $\begin{array}{c}\text { Kedalaman } \\
\text { pirit } \\
\text { (cm) }\end{array}$ & $\begin{array}{c}\text { Tinggi } \\
\text { Tanaman } \\
\text { (cm) }\end{array}$ & $\begin{array}{c}\text { Jumlah } \\
\text { anak } \\
\text { Daun }\end{array}$ \\
\hline Typic Sulfaquepts & 457 & 50 & 171 & 274 \\
& 416 & 50 & 104 & 242 \\
& 136 & 50 & 117 & 266 \\
\hline & & Rerata & $131^{n s}$ & $260^{\text {ns }}$ \\
\hline \multirow{3}{*}{ Sulfic Endoaquepts } & 216 & 100 & 433 & 332 \\
& 417 & 100 & 158 & 316 \\
& 976 & 100 & 139 & 304 \\
\hline
\end{tabular}

Keterangan: ${ }^{*}=$ beda nyata pada taraf $\alpha 5 \%$, ns = tidak beda nyata pada taraf $\alpha 5 \%$.

Pengamatan produktivitas kelapa sawit dengan tahun tanam 1998 yang dilakukan di daerah Betung Krawo menunjukkan bahwa produksi tanaman pada areal berpirit dalam lebih tinggi di bandingkan dengan produksi tanaman pada areal berpirit dangkal meskipun berdasarkan analisis sidik ragam tidak menunjukkan perbedaan yang nyata.
Pengamatan dilakukan pada tahun 2005-2007. Pada kedalaman lapisan pirit $100 \mathrm{~cm}$, yang berarti bahwa lapisan pirit selalu berada di bawah permukaan air tanah, tanaman tahun tanam $1998 \quad$ menunjukkan produktivitas sebesar 2,95 dan 4,25 ton TBS/ha/tahun masing-masing pada tahun 2005 dan 2006, jauh melebihi produktivitas pada kondisi 
pirit dangkal yang hanya mampu menghasilkan 1,78 dan 2,96 ton TBS/ha/thn pada tahun yang sama (Tabel 4).Perbedaan produktivitas TBS tersebut berasal dari adanya perbedaan berat tandan maupun jumlah tandan yang dihasilkan tanaman. Data pengamatan secara lengkap tersaji dalam Tabel 5. Produktivitas tanaman daerah Betung Krawo ini dinilai belum optimal jika dibandingkan dengan hasil pengamatan produktivitas kelapa sawit di Air Kumbang Padang, Banyuasin yang dilakukan Sutarta et al. (2008). Hasil pengamatan Sutarta et al. (2008) menunjukkan bahwa dengan pengelolaan lahan yang cukup optimal, produktivitas tanaman umur 5 dan 9 tahun pada lahan sulfat masam dengan kedalaman pirit $100 \mathrm{~cm}$ mencapai 18,27 dan 15,26 ton/ha/tahun.

Tabel 5. Produksi tanaman tahun tanam 1998 pada kedalaman pirit yang berbeda

\begin{tabular}{|c|c|c|c|c|c|c|c|c|c|c|}
\hline \multirow{2}{*}{ Jenis Tanah } & \multirow{2}{*}{ Blok } & \multicolumn{3}{|c|}{$\begin{array}{c}\text { Produktivitas } \\
\text { (ton TBS/ha/tahun) }\end{array}$} & \multicolumn{3}{|c|}{$\begin{array}{c}\text { Rerata Berat Tandan } \\
(\mathrm{kg})\end{array}$} & \multicolumn{3}{|c|}{$\begin{array}{c}\text { Jumlah } \\
\text { Tandan/Pohon } \\
\end{array}$} \\
\hline & & 2005 & 2006 & $2007 *$ & 2005 & 2006 & $2007 *$ & $\begin{array}{c}200 \\
5 \\
\end{array}$ & 2006 & $\begin{array}{c}2007 \\
* \\
\end{array}$ \\
\hline \multirow{4}{*}{$\begin{array}{l}\text { Sulfic } \\
\text { Endoaquepts } \\
\text { (kedalaman } \\
\text { pirit } 100 \mathrm{~cm} \text { ) }\end{array}$} & 136 & 2,693 & 4,529 & 1,523 & 4.79 & 4.30 & 4.30 & 5 & 9 & 3 \\
\hline & 216 & 3,759 & 4,384 & 1,513 & 4.23 & 5.80 & 5.96 & 7 & 6 & 2 \\
\hline & 976 & 2,389 & 3,849 & 1,203 & 3.82 & 3.50 & 4.09 & 5 & 9 & 2 \\
\hline & Rerata & $\underset{n s}{2,947}$ & $\underset{n s}{4,254}$ & $\underset{n s}{\mathbf{1 , 4 1 3}}$ & $4.28^{n s}$ & $4.53^{n s}$ & $4.78^{n s}$ & $6^{n s}$ & $\mathbf{8}^{n s}$ & $3^{n s}$ \\
\hline \multirow{4}{*}{$\begin{array}{l}\text { Typic } \\
\text { Sulfaquepts } \\
\text { (kedalaman } \\
\text { pirit } 50 \mathrm{~cm} \text { ) }\end{array}$} & 416 & 1,704 & 3,292 & 0,809 & 4.21 & 4.40 & 4.69 & 3 & 6 & 1 \\
\hline & 417 & 1,765 & 2,512 & 0,929 & 4.40 & 4.50 & 4.35 & 3 & 5 & 2 \\
\hline & 457 & 1,863 & 3,088 & 0,968 & 4.31 & 4.70 & 5.08 & 4 & 5 & 2 \\
\hline & Rerata & $\begin{array}{c}\mathbf{1 , 7 7 7} \\
n s\end{array}$ & $\underset{n s}{2,964}$ & $\underset{n s}{\mathbf{0 , 9 0 2}}$ & $4.31 n s$ & $4.53 n s$ & $4.71 n s$ & $3^{n s}$ & $\mathbf{5}^{n s}$ & $2^{n s}$ \\
\hline
\end{tabular}

Keterangan : ${ }^{*}$ ) produksi s/d bulan Agustus 2007; ns = tidak beda nyata pada taraf $\alpha$ 5\%

Pertumbuhan dan potensi produktivitas tanaman kelapa sawit di lahan rawa pasang surut cukup beragam terngantung pada kondisi lahan dan tingkat pengelolaan yang dilakukan. Hasil percobaan penanaman kelapa sawit di areal pasang surut oleh Kanaphaty dalam Pangudijatno (1990) dengan teknik drainase yang baik mampu menghasilkan 25 ton TBS/ha/tahun. Winarna et al. (2007) melaporkan bahwa produktivitas tanaman kelapa sawit pada lahan gambut saprik dapat mencapai 27 ton TBS/ha/thn jika dikelola dengan baik
(Tabel 2). Sementara Sutarta et al. (2008a) menyebutkan bahwa produktivitas kelapa sawit umur 5 tahun pada lahan pasang surut (sulfat masam) di Sumatera Selatan dengan pengelolaan lahan yang baik dapat mencapai 18,27 ton TBS/ha/tahun. Toh et. al. (1989) juga menyebutkan bahwa produktivitas tanaman pada areal rawa pasang surut umur 5 tahun di Carey Island, Sementanjung Malaysia sangat baik yaitu dapat mencapai 19 - 22 ton TBS/ha pada tanaman kelapa sawit. 


\section{Strategi pengelolaan lahan rawa pasang surut untuk pertumbuhan kelapa sawit yang optimum.}

\section{Penilaian kelayakan lahan secara umum}

Studi kelayakan merupakan pra syarat dasar yang menentukan keberhasilan pengembangan kelapa sawit di lahan rawa pasang surut. Karakteristik khas daerah lahan pasang surut yang harus diketahui untuk kesesuaian budidaya kelapa sawit antara lain yaitu kedalaman lapisan pirit, frekuensi dan lama genangan, $\mathrm{pH}$ tanah, salinitas, kematangan dan kedalaman gambut, dan proyeksi keperluan dana investasi pembangunan kebun sebaiknya sudah diidentifikasi serta dianalisis pada saat studi kelayakan. Hal ini penting sebagai dasar dalam menentukan kebijakan selanjutnya untuk mengembangkan kelapa sawit di lahan rawa pasang surut. Apabila hasil studi kelayakan menunjukkan bahwa tingkat produksi kelapa sawit yang diharapkan akan sulit tercapai akibat terdapat faktor pembatas berat yang permanen, maka dapat segera diambil keputusan untuk tidak melaksanakan usaha pengembangan kelapa sawit di lahan rawa pasang surut tersebut tetapi diarahkan ke penggunaan lain atau untuk areal konservasi. Kedalaman yang masih dapat dipertimbangkan sesuai untuk pengembangan kelapa sawit yaitu pada kedalaman 95-125 dengan syarat muka air tanah dapat dipertahankan pada level sekitar $60 \mathrm{~cm}$.

\section{Pengelolaan tata air}

Sistem tata air yang dibangun di kebun kelapa sawit tersebut harus mampu menjawab tantangan utama pada lahan rawa pasang surut, yaitu kemasaman tanah yang tinggi dan drainase yang buruk (Subagyono dan Susanti, 1998). Sistem tata air mencakup penataan dan pengelolaan jaringan tata air sehingga dapat menciptakan kondisi yang optimum untuk pertumbuhan dan produksi kelapa sawit, yaitu menciptakan kondisi yang optimum untuk aerasi perakaran sekaligus menghindari proses oksidasi pirit. Dengan demikian, kegiatan utama pada pengelolaan tata air ini mencakup: 1) pemanfaatan air pasang untuk mempertahankan muka air tanah, 2) mencegah akumulasi garam pada daerah perakaran, 3) mencuci zat-zat beracun bagi tanaman, 4) mengurangi oksidasi pirit (Widjaya-Adhi dan Alamsyah, 1998).

Sistem tata air yang baik bermanfaat untuk menurunkan permukaan air tanah hingga kedalaman $60 \mathrm{~cm}$ di bawah permukaan tanah, sekaligus menyediakan hara yang berasal dari pelapukan gambut. Terdapat berbagai pola atau bentuk tata air yang telah dikembangkan oleh berbagai pihak di lahan rawa rawa pasang surut, disesuaikan dengan kondisi lahan dan kemampuan petani. Sebagai contoh berbagai pola yang dikembangkan di lahan rawa pasang surut Sumatera Selatan dikemukakan oleh Subagyono et al (1998). Namun demikian, secara umum sistem tata air terdiri atas 3 komponen utama, yaitu benteng, parit, dan pintu air atau yang lebih dikenal dengan sebutan "Trio tata air" oleh Disbun Riau (1988).

\section{Perbaikan sifat kimia tanah}

Perbaikan sifat kimia tanah pada lahan rawa pasang surut meliputi perbaikan status hara makro, perbaikan kemasaman tanah, mencegah peningkatan kemasaman tanah, dan perbaikan status hara mikro pada lahan rawa pasang surut yang didominasi tanah gambut. Alternatif pengelolaan yang dapat dilakukan adalah aplikasi bahan pembenah tanah yang mempunyai efek pengapuran (liming effect), pencucian sulfat masam (Noorsyamsi dan Sarwani, 1989), dan aplikasi pupuk yang sesuai kaidah 4 T (tepat Jenis, Dosis, Waktu, dan Metode). Aplikasi pupuk mikro dan 
bahan pembenah tanah pada lahan gambut telah dikenal lama, baik pada tanaman kelapa maupun kelapa sawit. Aplikasi $15 \mathrm{~g} \mathrm{CuSO}_{4}$ dan $15 \mathrm{~g} \mathrm{ZnSO}_{4}$ dilakukan pada lubang tanam, selain 250 g RP dan 250g dolomit per pohon telah dilaporkan oleh Suandi dan Chan (1989). Selanjutnya pupuk mikro untuk tanaman menghasilkan diberikan setiap tahun dengan dosis 100 - 150 g per phn baik $\mathrm{CuSO}_{4}, \mathrm{ZnSO}_{4}$ maupun $\mathrm{FeSO}_{4}$ (Lim, 2006). Sementara pada perkebunan rakyat, yang biasa dilakukan adalah aplikasi trusi $\left(\mathrm{CuSO}_{4}\right)$ dan dolomit (Sutarta, 1989). Dalam perkembangannya untuk mengontrol pelepasan hara $\mathrm{Cu}$ dan $\mathrm{Zn}$ dari pupuk, saat ini telah banyak tersedia di pasar pupuk $\mathrm{Cu}$ dan $\mathrm{Zn}$ yang di-khelat (Cu-EDTA dan Zn-EDTA) (Lim, 2006).

Pada lahan rawa pasang surut yang cenderung masam, penggunaan jenis-jenis pupuk yang bereaksi masam sebaiknya dihindari. Dengan demikian, untuk sumber $\mathrm{N}$ aplikasi urea akan lebih baik dibandingkan dengan ZA yang bereaksi lebih masam di dalam tanah. Khusus untuk aplikasi pupuk $\mathrm{Mg}$, aplikasi dolomite akan lebih baik dibandingkan dengan kiserit, yang terkait dengan sifat pupuk dolomit yang memiliki efek pengapuran (liming effect). Sebagai akibat tidak seimbangnya kandungan kation pada tanah gambut, menyebabkan pada kondisi tertentu diperlukan aplikasi pupuk $\mathrm{K}$ dalam jumlah yang tinggi. Untuk mengatasi masalah defisiensi hara $\mathrm{K}$ pada lahan gambut, banyak direkomendasikan untuk melakukan pemupukan $\mathrm{K}$ dengan dosis yang cukup tinggi. Sugiyono et al. (1999) maupun Lim (2005) merekomendasikan perlunya aplikasi pupuk $\mathrm{KCl}(\mathrm{MoP})$ pada tanaman menghasilkan hingga 5-6 $\mathrm{kg} / \mathrm{phn} / \mathrm{thn}$, sedangkan aplikasi pupuk dolomite diberikan dalam jumlah sedikit dan RP kurang dari 1 kg/phn/tahun.

\section{SIMPULAN}

Lahan rawa pasang surut di Indonesia merupakan salah satu lahan marjinal yang berpotensi untuk pengembangan kelapa sawit. Untuk mencapai produktivitas tanaman yang tinggi, beberapa kendala seperti drainase yang sangat terhambat, salinitas yang tinggi, dan potensi kandungan pirit harus diatasi dengan baik. Hasil pengamatan vegetatif (leaf area) tanaman kelapa sawit umur 2 tahun di daerah rawa pitu (kedalaman pirit 80$100 \mathrm{~cm}$ ) menunjukkan bahwa pengelolan air dengan tinggi muka air 20-40 cm memiliki leaf area yang lebih besar $(2,93$ $\mathrm{m}^{2}$ ) dibandingkan dengan pengelolaan air 0-20 cm $\left(2,40 \mathrm{~m}^{2}\right)$ dan 40-60 $\mathrm{cm}(2,21$ $\left.\mathrm{m}^{2}\right)$ di bawah permukaan tanah. Pengamatan produktivitas kelapa sawit dengan tahun tanam 1998 yang dilakukan di daerah Betung Krawo menunjukkan bahwa produksi tanaman pada areal berpirit dalam lebih tinggi di bandingkan dengan produksi tanaman pada areal berpirit dangkal. Strategi pengelolaan lahan rawa pasang surut untuk mencapai pertumbuhan dan produktivitas tanaman yang optimim antara lain dengan melakukan: penilaian kelas kesesuaian lahan sebelum dilakukan pengembangan kebun, pengelolaan tata air yang baik, dan perbaikan sifat kimia tanah.

\section{DAFTAR PUSTAKA}

Hakim N/, M. Y. Nyakpa, A. M. Lubis, S. G. Nugroho, M. R. Saul, M.A. Diha, G. B. Hong, dan H. H. Bailey. 1986. Dasar- Dasar Ilmu Tanah. Badan Penerbit Universitas Lampung. Lampung. 488 p.

Harahap, I. Y. dan H. H. Siregar. 2004. Evaluasi dan Rekomendasi Kultur Teknis Tanaman Kelapa 
Sawit pada Lahan Basah Unit Usaha Betung Krawo, Sumatera Selatan PT. Perkebunan Nusantara VII, Laporan Ekstern Pusat Penelitian Kelapa Sawit, Medan

Kimpraswil-online, 2006. www.tidallowland.com

Leiwakabessy, F. 1980. Pengembangan pertanian di daerah transmigrasi dan permasalahannya. Publ. PPTLIPB Bogor dan Ditjen Transmigrasi.

Lim, K. H. 2005. Soil, Water, and Fertilizer Management for Oil Palm Cultivition on Peat Soils. Proceedings of the PIPOC 2005 International Palm Oil Congress. p: 433-455.

Lim, K.H. 2006. Sustainable Oil Palm Planting on Tropical Peat Soil. Proceedings of International Oil Plam Conference, Indonesian Oil Palm Research Institute, Bali 19 - 23 June 2006.

Noorsyamsi dan Sarwani, 1989. Management of Tidal Swamp Land for Food Crops; Southern Kalimantan Experiences. IARD Journal 11 (1\&2).p 1824.

Suandi, dan Fidber Chan. 1989. Suatu tinjauan tentang permasalahan dan pencegahan masalah dalam pemanfaatan lahan gambut untuk pertanaman kelapa sawit. Prosiding Seminar Tanah Gambut untuk Perluasan Pertanian. UISU. Medan, 27 November 1989. p: 226 - 237.

Sugiyono. R. Sukarji. dan E.S. Sutarta. 1999. Pemupukan N. P. K. dan $\mathrm{Mg}$ untuk tanaman kelapa sawit pada lahan gambut. Jurnal Penelitian Kelapa Sawit 7(1): $17-31$.
Suriadikarta, D.A. 2005. Pengelolaan Lahan Sulfat Masam untuk Usaha Pertanian. Jurnal Penelitian dan Pengembangan Pertanian. Vol. 24 (1).

Sutarta, E.S., S. Rahutomo, Winarna, dan D. Wiratmoko. 2008. Laporan Rekomendasi Pemupukan Tanaman Kelapa Sawit Menghasilkan, Kebun Inti PT Andira Agro Tahun 2009.

Laporan ekstern (tidak dipublikasikan). Pusat Penelitian Kelapa Sawit.

Sutarta, Edy Sigit. 1989. Prospek pengembangan kelapa di lahan gambut. Prosiding Seminar Tanah Gambut untuk Perluasan Pertanian. UISU. Medan, 27 November 1989. p: $215-225$.

Toh , P.Y., C. Baskett, and A. Abdullah. 1989. Reklamation of Mangrove Swamp for Oil Palm Cultivation. Intern. Oil Palm/Palm Oil Conference. Kuala Lumpur. p : 419-427.

Widjaya-Adhi, I.P.G. dan T. Alihamsyah, 1998. Pengembangan Lahan Pasang Surut : Potensi, Prospek dan Kendala serta Teknologi Pengelolaannya untuk Pertanian.

Pangudijatno, G. 1990. Reklamasi sulfat masam untuk Perkebunan Kelapa Sawit. Buletin Perkebunan Puslitbun Medan 21 (1) : 27-37.

Statistik Perkebunan Indonesia 20122014 : Kelapa Sawit. Direktorat Jenderal Perkebunan, Kementerian Pertanian, 2013.

Subagyono, K. dan E. Susanti, 1998. Sistem Aliran Satu Arah sebagai Alternatif Strategi Pengelolaan Air di Lahan Pasang Surut. Prosiding Seminar Nasional dan Pertemuan Tahunan 
Komisariat Daerah Himpunan Ilmu Tanah Indonesia, p : 347 354.

Widjaya-Adhi, I.P.G. dan T. Alihamsyah, 1998. Pengembangan Lahan Pasang Surut : Potensi, Prospek dan Kendala serta Teknologi Pengelolaannya untuk Pertanian.

Subagyono, K. dan E. Susanti, 1998. Sistem Aliran Satu Arah sebagai Alternatif Strategi Pengelolaan Air di Lahan Pasang Surut. Prosiding Seminar Nasional dan Pertemuan Tahunan Komisariat Daerah Himpunan Ilmu Tanah Indonesia, p : 347 354.

Disbun Riau. 1988. Keunggulan dan Kelemahan Tanah Gambut sebagai Lahan Pengembangan Komoditi Perkebunan pada Umumnya dan Kelapa Hibrida Khususnya. Riau, 19 p.

Winarna, D. Wiratmoko, E.S. Sutarta, S. Rahutomo, dan Sujadi (2007) Potensi dan Kendala Lahan Rawa Pasang Surut Untuk Budidaya Tanaman Kelapa Sawit. Prosiding Seminar Nasional Pertanian Lahan Rawa. Kuala Kapuas, 3-4 Agustus 2007. P: 223 - 235. 